\title{
HOW FIRM SIZE MODERATES THE KNOWLEDGE AND AFFECTS THE INNOVATION PERFORMANCE? EVIDENCE FROM BRAZILIAN MANUFACTURING FIRMS
}

\author{
(iD) Marco Túlio Dinali Viglioni ${ }^{1}$ (D) Cristina Lelis Leal Calegario $^{2}$
}

\author{
${ }^{I}$ Doutorando, Universidade Federal de Lavras - UFLA, Departamento de Administração. Lavras, MG - Brasil. \\ marcotuliodinali@gmail.com \\ ${ }^{2}$ PhD, professora titular, Universidade Federal de Lavras - UFLA, Departamento de Administração. Lavras, MG - Brasil. \\ ccalegario@ufla.br
}

\section{Abstract}

Objective: Consists in explore the relationship between firm size and knowledge to capture the firm innovation performance in Brazilian manufacturing industries.

Methodology: Using the production function approach and following the Resource-Based-View - RBV theory, we investigate how the firm internal $R \& D$ and the degree of intangible assets are moderated by firm size. Originality: The literature in the past decades has tried different methods to find strategies that improve the innovation of a large number of firms in different countries and regions. Yet, there is a large number of firms from emerging economies looking forward to improve productivity and the firm innovation performance.

Main results: The results indicated that investment in $R \& D$ is relevant to the firm performance. Nonetheless, the relationship between R\&D and firm size showed negative results. In the case of the degree of intangible resources, the same was observed, but the interaction between firm size and intangible assets showed positive effects on the firm performance. Finally, other important characteristics were observed, such as firm age and technology intensity, which showed positive influence over the firm performance.

Theoretical contributions: The study showed that the degree of intangible assets is relevant for the firm, as the theory predicts, and it has become valuable for emerging enterprises, once not all firms may conduct $R \& D$ activities.

Social contributions: The findings update the understanding about R\&D and other intangible assets and provide new information to managers, researchers, and policymakers to develop new policies to promote and finance these activities.

Keywords: Innovation. Productivity. Research and development. Intangibles assets. Brazil.

\section{COMO O TAMANHO DA EMPRESA MODERA O} CONHECIMENTO E AFETA O DESEMPENHO EM INOVAÇÃO? EVIDÊNCIAS DAS EMPRESAS MANUFATUREIRAS DO BRASIL

\section{Resumo}

Objetivo: Consiste em explorar a relação entre tamanho da empresa e o conhecimento para capturar o desempenho da inovação das firmas manufatureiras brasileiras.

Metodologia: Utilizando uma abordagem por meio da função da produção e seguindo a teoria da visão baseada em recursos - RBV, investigamos como a P\&D interna da empresa e o nível de ativos intangíveis são moderados pelo tamanho da empresa.

Originalidade: A literatura nas últimas décadas tentou métodos diferentes para encontrar estratégias que melhoram a inovação para um grande número de empresas em diferentes países e regiões. No entanto, há um grande número de empresas de economias emergentes e em desenvolvimento que desejam melhorar a produtividade e o desempenho da inovação da empresa.

Principais resultados: Os resultados indicam que o investimento em P\&D é relevante para o desempenho da empresa. No entanto, a relação entre $P \& D$ e o tamanho da empresa demonstra resultados negativos. No caso do grau de recursos intangíveis, o mesmo foi observado. Entretanto, a interação entre o tamanho da empresa e ativos intangíveis indicou efeitos positivos para o desempenho da empresa. Por fim, outras características importantes foram observadas, tais como a idade e a intensidade tecnológica das empresas, mostrando influência positiva sobre o desempenho.

Contribuição teórica: $\mathrm{O}$ estudo demonstrou que o grau de ativos intangíveis é relevante para a empresa, tal como a teoria afirma. Além disso, os ativos intangíveis se revelaram valiosos para empresas emergentes, uma vez que nem todas podem realizar as atividades de $\mathrm{P} \& \mathrm{D}$.

Contribuição social: As conclusões atualizam o entendimento sobre a P\&D e outros ativos intangíveis e fornecem novas informações aos gestores, pesquisadores e formuladores de políticas para desenvolver novas políticas para promover e financiar essas atividades.

Palavras-chave: Inovação. Produtividade. Pesquisa e desenvolvimento. Ativos intangíveis. Brasil.

\section{¿CÓMO MODERA EL TAMAÑO DE LA EMPRESA EL CONOCIMIENTO Y AFECTA EL DESEMPEÑO EN INNOVACIÓN? EVIDENCIA DE LAS EMPRESAS FABRICANTES DE BRASIL}

\section{Resumen}

Objetivo del trabajo: El objetivo es explorar la relación entre el tamaño de la empresa y el conocimiento para capturar el desempeño en innovación de las empresas manufactureras brasileñas.

Metodología: Utilizando un enfoque que utiliza la función de producción y siguiendo la teoría de la visión basada en recursos - RBV, investigamos cómo la I + D interna de la empresa y el nivel de activos intangibles son moderados por el tamaño de la empresa.

Originalidad: La literatura en las últimas décadas ha probado diferentes métodos para encontrar estrategias que mejoren la innovación para un gran número de empresas en diferentes países y regiones. Sin embargo, hay una gran cantidad de empresas de economías emergentes y en desarrollo que desean mejorar la productividad y el desempeño de innovación de la empresa. Principales resultados: Los resultados indican que la inversión en I + D + i es relevante para el desempeño de la empresa. Sin embargo, la relación entre $\mathrm{I}+\mathrm{D}+\mathrm{i}$ y el tamaño de la empresa arroja resultados negativos. En el caso del grado de recursos intangibles, se observó lo mismo. Sin embargo, la interacción entre el tamaño de la empresa y los activos intangibles indicó efectos positivos para el desempeño de la empresa. Finalmente, se observaron otras características importantes, como la edad e intensidad tecnológica de las empresas, que muestran una influencia positiva en el desempeño.

Contribuciones teóricas: El estudio demostró que el grado de intangible es relevante para la empresa, tal y como establece la teoría. Además, los activos intangibles han demostrado ser valiosos para las empresas emergentes, ya que no todas pueden realizar actividades de $\mathrm{I}+\mathrm{D}+\mathrm{i}$.

Contribuciones sociales: Los hallazgos actualizan la comprensión de la I + D y otros activos intangibles y proporcionan nueva información para que los administradores, investigadores y responsables políticos desarrollen nuevas políticas para promover y financiar estas actividades.

Palabras-clave: Innovación. Productividad. Investigación y desarrollo. Activos intangibles. Brasil.

\section{Cite as / Como citar}

American Psychological Association (APA)

Viglioni, M. T. D., \& Calegario, C. L. L. (2021, Special Issue, March). How firm size moderates the knowledge and affects the innovation performance? Evidence from brazilian manufacturing firms. Iberoamerican Journal of Strategic Management (IJSM), 20, p. 1-20, e15567.

https://doi.org/10.5585/riae.v20i1.15567.

VIGLIONI, M. T. D.; CALEGARIO, C. L. L. How firm size moderates the knowledge and affects the innovation performance? Evidence from brazilian manufacturing firms. Iberoamerican Journal of Strategic Management (IJSM), v. 20, Special Issue, p. 1-20, e15567. Mar. 2021.

https://doi.org/10.5585/riae.v20i1.15567. 
Science, technology and innovation (STI) have a pervasive and growing presence in all human activity (Navarro et al., 2016) and the modern economy is influenced in countless ways by the advance of science and technology (Mansfield et al., 1971). In a modern economy, the technological advances and innovation strategy are not a new phenomenon at micro- and macro-level data in advanced economies (Carboni \& Medda, 2019; Hall \& Mairesse, 1995; Kafouros et al., 2009). In the $20^{\text {th }}$ century, industrial Research and Development (R\&D) has become the engine that drives not only technological advances and innovations (Kafouros, 2008b), but also improves national and regional economic development (Crespi \& Zuniga, 2012; Kafouros et al., 2009).

In all countries whose firms invest in $\mathrm{R} \& \mathrm{D}$, firms are more able to introduce new technological advances and improve productivity (Crespi \& Zuniga, 2012; Kafouros, 2008b). However, R\&D projects involve technical and market uncertainty, once it cannot be sure that will always lead to technological breakthroughs (Kafouros, 2008a). Companies in emerging economies are in search of complementary assets, once R\&D investments can be prohibitive for several firms (Crespi et al., 2014). There are alternatives to $R \& D$ investments that may promote firm performance, based on other intangibles assets (Carvalho et al., 2010; Kayo et al., 2006). Intangible assets have received large attention in the fields of business, management, accounting, and economics (Bontempi \& Mairesse, 2015; Denicolai et al., 2015; Kayo et al., 2006; Kramer et al., 2011), once it contributes to the firm value creation (Carvalho et al., 2010; Kafouros \& Aliyev, 2016; Kayo \& Famá, 2004), such as brands, consumers' preference and their perception of the products or services (Bontempi \& Mairesse, 2015; Carvalho et al., 2010; Frank et al., 2016).

Another important factor that contributes to foster the firm innovation performance relies on the firm size. Size is an indicator of managerial and financial resources (Penrose, 1959) and is welldocumented in the empirical literature, besides shown controversial results (Aboal et al., 2015; Kafouros et al., 2009). Researchers identified that large and technology-intensive firms, in general, shows higher performance (Aboal et al., 2015; Berchicci, 2013; Kafouros et al., 2009), whilst others argued in the opposed direction (Denicolai et al., 2015; Shefer \& Frenkel, 2005). To shed more light on the firm innovation performance, the objective of this research is to understand how firm size moderates the firm knowledge and improve the innovation performance in Brazilian manufacturing firms. Adopting the production function approach and following the Resource-Based-View - RBV theory, we investigate how the firm internal $R \& D$ and the degree of intangible assets are moderated by firm size. To capture this effect, we adopted a firm-level panel data using the financial consolidated data available for firms listed in the Brazilian Securities and Exchange Commission (CVM) and B3 S.A from 2009 to 2018 (540 observations).

The contributions to the innovation and RBV literature are threefold. First, the study of intangible assets has received increasing attention by scholars from management and accounting science, recognizing that immaterial assets yield critical returns to a firm value creation (Kramer et al., 2011). We continue to contribute to the RBV theory (Barney, 1991) regarding emerging 
economies, using the degree of intangibility proposed by Kayo et al. (2006), once R\&D activities are more oriented to product and process activities (Kafouros, 2008a). Second, investigating emerging market environment improves the explanatory power of the RBV, as long as these economies developed unique resources and activities not necessarily related to R\&D expenditures (Crespi \& Zuniga, 2012). In such environment, the focus on intangible assets is interesting, because they are difficult to imitate and protected by property rights or high-levels of specificity. This focus refutes the long-held idea that firms from emerging countries generally do not have intangible resources such as know-how and patents (Dierickx \& Cool, 1989; Kayo et al., 2006). Nonetheless, the degree to which intangible assets can contribute to companies in an emerging economy is hard to predict theoretically as there is no conclusive evidence or argument about how resilient they are in emerging contexts (Andonova \& Ruíz-Pava, 2016). In the particular case of emerging economies, regarding Brazil, the role of intangible is also recognized (Carvalho et al., 2010; Kayo \& Famá, 2004; Kayo et al., 2006), even though, the literate explain that the number of studies is much lower (Andonova \& Ruíz-Pava, 2016).

Third, past researches adopted different moderators, such as firm age to check firm growth (Anderson \& Eshima, 2013). Despite that, the literature did not identify studies aimed at investigating firm size as a moderator variable (Denicolai et al., 2015). Complementing previous work, we chose the firm size once after Schumpeter's (1942) work, when the author exposed that the large size and technology firms are better innovators, a profuse number of researchers started to test empirically these two theoretical predictions, which becomes a noticeable issue in the field of technology management (Shefer \& Frenkel, 2005; Tsai, 2005). Additionally, we checked the firm technology intensity, once firms from high-technology sectors, in general, show high R\&D expenditure (Dunning \& Lundan, 2008) and may be influenced mainly by the levels of intangible assets related to R\&D (Kayo et al., 2006). Finally, considering these features is important once the returns on intangible assets is a subject of considerable concern for policy-makers, firm managers, and researchers (Bontempi \& Mairesse, 2016). The findings will update the understanding of $R \& D$ and other intangible assets to help managers, researchers, and policymakers to develop new policies to promote and finance these two major activities.

This paper is structured as follows. Section 1 presents the theoretical background followed by the hypothesis's development. Section 2 describes the Methodology, variables, and data. Section 3 discusses the Results. Finally, the last section draws the Conclusions and managerial and policy implications.

\section{Theoretical background and hypotheses}

Since the work of Joseph Schumpeter (1942) "Capitalism, socialism and democracy" and the seminal paper of Robert Solow (1956) "A Contribution to the theory of economic growth", knowledge has repeatedly been found as the main determinant of technological progress. After the work of Zvi Griliches (1979), considering the R\&D expenditures at the firm-level, the related literature dramatically 
increased. The contribution of $R \& D$ to productivity at the firm-level is one of the most important, in order to assess the role of technical progress in economic growth (Bontempi \& Mairesse, 2015). Indeed, innovation activities, particularly $R \& D$ investment, are fundamental to developing new competencies and the skills needed to seek, acquire, and adapt existing technology (Navarro et al., 2016).

Yet, the way that firms innovate and engage in the technology race is much more complex and is not solely limited to internal $R \& D$ capacity, once most of the firms in emerging markets are engaged in activities far from the technological frontier (Alcorta \& Peres, 1998; Crespi \& Zuniga, 2012). Innovation activity is a wide concept, ranging from the invention of new products and services, the improvement of productive, organizational, and operational techniques, to the creation of a unique public image of a product's quality (Bontempi \& Mairesse, 2015). Past researches indicate that R\&D is positively correlated to the level of investment intensity, which suggests that there is a potential complementarity between intangible assets and firm' investments (Carboni \& Medda, 2019; Kafouros \& Aliyev, 2016; Kafouros et al., 2009). For instance, intangible assets have been increasingly seen as critical drivers for knowledge creation, innovation, and consequently economic growth (Kramer et al., 2011). As such, intangible assets consists of the stock of immaterial resources (Arrighetti et al., 2014) that contribute to the search for important firm competitive benefits (Kayo et al., 2006), such as organizational capabilities, higher brand awareness, increased service-levels, ability to networking and to boost the corporate performance (Frank et al., 2016; Kramer et al., 2011; Luca et al., 2014).

The background literature behind intangible assets relies on the Resource-Based View - RBV. The RBV theory stands out that firm-specific heterogeneity, in terms of resources and capabilities, determines firms' strategic choices (Barney, 1991; Dierickx \& Cool 1989). The RBV relies on who controls a single and specific asset; which means those who own or rigidly control such assets have a competitive advantage (James, 2002; Kayo et al., 2006) gathered from the resources used by the company that is scarce and difficult to imitate (Peteraf \& Barney, 2003). Nevertheless, establishing a definition of intangible assets is not an easy task (Kayo \& Famá, 2004), once the RBV defines a company as a set of features and capabilities (Gantumur \& Stephan, 2012).

Barney (2001) points out that the RBV is not able to generate a list of specific resources, but it is able to specify the resources that may be used to obtain competitive advantages. Lev (2001) created an intangible assets taxonomy, divided into 4 major parts: (1) academic and tacit knowledge of its employees; (2) processes that facilitate the transfer and acquisition of knowledge; (3) relationship with customers, suppliers, and the labor market; and (4) training in research and development. Apart from these, Hall (1992) classifies intangible assets or skills. In the case of assets, those can be defined as the intellectual property rights, patents, trademarks, copyright, and registered designs, as well as contracts, trade secrets, and databases, whilst skills include the know-how of employees and the collective attitudes which add up to organizational culture.

Considering these many aspects, the multiple resources and capacity of different companies may be one of the main reasons for the persistent heterogeneity in company performance levels (Gantumur 
\& Stephan, 2012). As such, Carvalho et al. (2010) state that the central proposition of RBV theory is the source of the competitive advantage and how it creates wealth for companies. For instance, this approach focuses on the characteristics of a firm valuable resources and capabilities, and which, by the way, competing companies find it difficult to create on their own (Carvalho et al., 2010; Gantumur \& Stephan, 2012).

By using these arguments, we expect that firm internal R\&D capacity and the firm degree of intangible assets are moderated by firm size, especially considering if they will be able to extract value from these resources to improve the innovative performance output. The next session of this work comprehends each of these strategies, its respective hypothesis and describes what has been said about them in the literature in the last years.

\section{The role of internal $R \& D$ and firm performance}

Economic growth theorists and management scholars have long recognized the crucial role that R\&D plays in triggering technological advances and in improving national and regional economic development (Kafouros et al., 2009). As such, R\&D and its evaluation have attracted wide interest by researchers, once it is a source of advantages for firms (Crespi et al., 2014). At the firm-level, R\&D is considered to be the strongest competitive weapon of many companies (Kafouros et al., 2009), leading to strong economic returns and consequently, developing new technologies (Berchicci, 2013; Kafouros \& Aliyev, 2016; Shefer \& Frenkel, 2005). In addition, R\&D might contribute to the development of collaborations and partnerships between firms and research institutions (Kafouros et al., 2009), which means it affects not only the scientific knowledge developed by the R\&D teams but the firm performance that undertake such activities (Berchicci, 2013; Kafouros, 2008a).

The past literature has investigated the R\&D effects and firm performance. Chudnovisky et al. (2006) analyzing the Argentinean manufacturing industry identified the importance of continually investing in $R \& D$ to improve the innovation output (product and process innovation). In the same line, Arza and Lopes (2010) estimated the relationship between innovation and productivity in Argentina and found that in-house activities seem to be the major contributor to success in product and process innovation. The study of Bravo-Ortega et al. (2014) found for Chilean firms that investment in R\&D activities are considerably more likely to export, but the reverse is not true. These authors argued that exporting does not drive investment in $R \& D$ per se, but exports and $R \& D$ have a joint effect, which means there is a loop among $R \& D$, productivity, exports and also learning-by-exporting effect.

Nonetheless, recent studies analyzed the influence of innovation on micro-small-and-mediumsized enterprises (MSME) in Colombia (Restrepo-Morales et al., 2019). They found that the innovation activities are carried informally and firms are uninterested to engage in R\&D activities and to develop new products by their own initiative. In the case of the Brazilian industry, Frank et al. (2016) argued that firms are more focused at the acquisition of assets, such as machinery and equipment to engage in 
innovative activities. However, the authors argued that such activity is losing strength in the last years, while in-house R\&D seems to recover. On the other hand, Viglioni and Calegario (2020) found evidence of high dependence on technology import, whilst R\&D activity, in short term, does not show effects over the innovation in Brazilian manufacturing industries. Accordingly, we introduce the following hypothesis:

Hypothesis 1: Firms with large internal $R \& D$ expenditure shows higher innovation performance.

\section{The role of intangible assets and the firm performance}

Over the last few years, mainly since the 1980s, intangible assets have reached an everincreasing proportion of corporate value (Kayo \& Famá, 2004). In the contemporary economy, competition between firms is more and more driven by the development and accumulation of intangible assets (Denicolai et al., 2015) and has particularly grown in importance in the formation of this value (Carvalho et al., 2010). The economic value of a company is a result of the sum of its tangible and intangible assets (Kayo et al., 2006). As the companies have relatively easy access to the acquisition of tangible assets (e.g., land, buildings, machinery, equipment, among others), the intangible portfolio offers an important differentiating factor, contributing decisively to increase the value creation of the assets (Carvalho et al., 2010). As such, intangible assets complement physical investments in the sense that they also contribute to establishing the conditions for creating productive resources (Alcorta \& Peres, 1998).

In the case of emerging economies, Andonova and Ruíz-Pava (2016) analyzing the context of Colombian firms identified the role of intangible assets as important determinants of firm performance and the result confirms the resilience of intangible assets such as brands, patents, know-how, franchising, and licenses. This explains a share of the firm performance, adding value by using intangible assets as a competitive lever. However, Carvalho et al. (2010) reported a negative effect on Brazilian firms. The authors conclude that investments in intangible assets were actually negatively associated with business performance. This may occur, once intangible assets are unable to upstand rivals because they reach a steady-state rather than growing in perpetuity (Fagerberg et al., 2010).

Additionally, differently from tangibles, intangible assets are more likely to market imperfections (Kafouros \& Aliyev, 2016), such as trademark and industrial secrets. Hence, the literature is not always consistent and does not conclude if the abundance of intangible resources is a relevant condition to generate innovative and profitable strategies (Bueno et al., 2010). Accordingly, we introduce the following hypothesis: 
Hypothesis 2: Investments in intangibles assets contributes positivelly to the firm innovation performance.

The role of firm size and the firm performance

The size of the investing firm, as well as the extent and location of its other foreign value-adding activities, are other relevant variables (Dunning \& Lundan, 2008). The literature stands out that, when the size of the firm is held constant, the number of significant inventions carried out seems to be highly correlated with the size of its R\&D expenditures (Mansfield et al., 1971). Hence the literature also investigates whether intangibles are sensitive to the firm size. Firm size could, in principle, affect the successful acquisition of tangible and intangible external assets (Denicolai et al., 2015; Viglioni et al., 2018). This occurs, once the firm size has been positively related to the existence of complementary assets within the firm (Anderson \& Eshima, 2013).

Using a panel for several European countries, Denicolai et al. (2015) found that external intangible assets additionally boosts the firm performance. Nonetheless, they concluded that firm size does not influence the performance per se, once the impact of intangibles on a firm growth varies according to its size, slowly decreasing as the company grows. On the other hand, Arrighetti et al., (2014) investigating Italian firms found that large-size firms significantly increase the probability of the firm to invest in intangible assets. Furthermore, Carboni and Medda (2019) analyzing several European countries found evidence of the relationship between $R \& D$ and investment is, in fact, a crucial issue for a firm growth, particularly considering the strong interaction between physical capital accumulation and technological progress.

In emerging economies, Chudnovisky et al. (2006) found that large-size firms from Argentina are more prone to engage in innovation activities, especially with in-house R\&D. In the same line, Bravo-Ortega et al. (2014) found for large size Chilean firms with R\&D division increased the probability to innovate both in service and manufacturing sectors. In spite of, Benavente (2006) suggests that the current R\&D expenditures on Chilean firms have no significant impact on current salesweighted innovations. Besides that, the author argued that it appears that larger firms tend to have more success in their innovative sales compared with their smaller counterparts. Other researchers identified that size is not related to innovation and productivity in Argentina, Chile, Panama, or Uruguay, and it has a negative significant association with productivity in Costa Rica (Crespi \& Zuniga, 2012).

Crespi et al. (2014) reported that SMEs are more handicapped to participate in the innovation race, limiting their potential to grow and become more competitive in international markets. They observed that size is the most important factor influencing the probability of spending in R\&D and IPR applications. As such, Kafouros et al. (2009) argued that smaller firms can reap higher returns to R\&D than larger firms, simply because they are more entrepreneurially-oriented and can commercialize inventions more efficiently. Indeed, in this environment, intangible assets such as technology, product 
designs, and trademarks (Kafouros \& Aliyev, 2016), contracts and trade secrets are typically protected, which makes it difficult to imitate (Dierickx \& Cool, 1989; Hall, 1992).

Thus, the RBV suggests that a firm size represents the organizational resource base for various activity expansions (Barney, 2001), being able to exploit economies of scale in intangible assets (Dierickx \& Cool, 1989) and being more effective in protecting their intangible stock than small ones (Arrighetti et al., 2014). Considering this, we expect that intangible asset to be important for large firms due to their protective nature, becoming more difficult for other firms to take advantage of this type of asset. Accordingly, we introduce the following hypotheses:

Hypothesis 3a: The firm innovation performance is positively moderated by the size of the firm and $R \& D$ expenditures.

Hypothesis 3b: The firm innovation performance is positively moderated by the size of the firm and intangible assets.

\section{Methodology}

\section{Estimating the model}

To test the empirical approach, how firm size influences the internal $R \& D$, and the degree of intangible asset, our methodology includes the estimation of a Cobb-Douglas production function, performed by Zvi Griliches (1979). Specifying and estimating the production function is important, once one of the most relevant features of this approach is the contribution of $R \& D$ and productivity at the firm level, in order to assess the role of technical progress in economic growth (Bontempi \& Mairesse, 2015). The production function correlated the output not only with the conventional inputs of Capital $(Q)$ and Labor $(L)$, but also with the level of scientific knowledge $(R)$ (e.g., Research and Development, intangibles assets, and other knowledge) as Equation (1) indicates.

$$
Q=f(K, L, R, \varepsilon)
$$

Ordinarily, logs are taken, converting it to a linear model that can be easily estimated as showed in Equation (2).

$$
q_{i t}=a e^{\lambda t} k_{i t}^{\alpha} l_{i t}^{\beta} r_{i t}^{\gamma} u^{\varepsilon i t}
$$


Following Kafouros (2008a, p. 84) we adopted the transformation of Equation (3), which assumes equality on marginal products $d Q / d R$ across firms. The definition of the elasticity or R\&D $(\gamma)$ is equal to $\frac{d Q R}{d R Q}$, recalling that the term $\gamma r$ can be rewritten as $\frac{d Q R d R}{d R Q R}$ or $\frac{d Q d R}{d R Q}$.

$$
q_{i, t}=a+\lambda t+\alpha k_{i, t}+\beta l_{i, t}+\gamma r_{i, t}+u_{i, t}
$$

Following past researches (Kafouros et al., 2008; Kafouros et al., 2009; Wakelin, 2001), we transformed Equation (4) in terms of firm innovative performance $(\Delta p)$. The marginal product of R\&D $(\rho)$ represents the rate of return to research/knowledge expenditure.

$$
\Delta p_{i, t}=\lambda+\alpha \Delta k_{i, t}+\beta \Delta l_{i, t}+\rho(r)_{i, t}+u_{i, t}
$$

Constant Return Scale (CRS) is assumed to the capital and labor. Where $\Delta x_{i t}=x_{i t}-x_{i t-1}$, $p_{i, t}$ is the economic performance of a firm $i$ at time $t$. The term $\lambda$ represents the rate of disembodied technical change, and the lower cases letters denoted by $(a)$ represents the constant, the term $(k)$ is the firm stock of capital, $(l)$ the labor variable and $(r)$ the R\&D capital or intangible assets of the firm. In order to reach our objectives, we transformed the Equation (4) including the size as a variable that weights the firm knowledge capital and control variables as described in Equation (5).

$$
\Delta p_{i, t}=\lambda+\alpha \Delta k_{i, t}+\beta \Delta l_{i, t}+\rho(r)_{i, t} \operatorname{Size}_{i, t}+\sum \gamma+\varphi+u_{i, t}
$$

Following the literature, we added time and industry dummies, once firm performances and characteristics vary over time and across industries (Kafouros, 2008b; Kafouros et al., 2009). Time $\gamma$ and industry $\varphi$ dummy captures any idiosyncrasy effects across time and industries. The residuals of the regression are represented by $u_{i, t}$. It is important to mention that, once we are handling economic variables and, such variables are not always linear across time, we take the natural logarithm to diminish the possibility of heteroskedasticity besides getting a better fit in the model. Finally, we conceptualize and measure the firm R\&D and intangible assets performance in separated models.

\section{Variables description}

Dependent variable represents the firm innovation performance. The performance can be measured by gross output, value-added, or sales (Hall et al., 2010). In the case of this research, the concept of value-added for innovation is relatively more important in manufacturing industries where 
value-added originates and knowledge skills are more valued (Crespi \& Zuniga, 2012). In addition, we adopted the concept of value-added once the literature considers a better proxy (Suzuki, 1985). Furthermore, the literature suggests the differences between sales and value-added are usually quite close (Kafouros, 2008b; Hall et al., 2010).

\section{Independent variables}

Capital intensity measures the technological intensity and, in some firms, extent sophistication. As a proxy for capital, it was chosen the concept of net fixed assets. However, it was not possible to deflate the fixed gross capital over time, adopting an industry deflator as the literature recommends (Kafouros, 2008a; Wakelin, 2001). Instead, we adopt the concept of net fixed assets, represented by gross fixed capital stock (e.g., investments, fixed capital goods, and intangibles assets) less short-term debts (e.g., bank loans, leases, and other bank financials).

Labor is commonly represented by the natural logarithm of the total number of employees in a firm-year (Kafouros et al., 2009; Wakelin, 2001). However, financial datasheet does not inform the firm physical-capital. To avoid this issue, it was adopted the concept of wages and salaries in a firm-year as a proxy for labor (Tsai, 2005). It is important to mention that the total employment is defined by the sum of wages and salaries, which includes all the profit sharing, social security costs, and all other employment costs. Nonetheless, once the R\&D composition considers the wages and salaries, these were not repeated to compose the firm $\mathrm{R} \& \mathrm{D}$ expenditure to avoid the possibility of double-counting.

\section{Research and Development and the rate of obsolescence}

To construct the firm stock of R\&D-Capital, we adopted a proxy following the OECD (2015) Frascati Manual, which suggests that there are three main R\&D components: Capital expenditure, Labor and other current expenditure (including plants, machinery, equipment, land, and buildings). As such, labor spending includes the salaries and wages devoted to R\&D personnel. To estimate the stock of R\&D-Capital, we follow Griliches (1979), adopting the perpetual inventory approach as Equation 6 indicates.

$$
\mathrm{R}_{\mathrm{it}}=\mathrm{RD}_{\mathrm{it}}+\sum_{1}^{k}(1-\delta)^{k} \mathrm{RD}_{\mathrm{i}(\mathrm{t}-\mathrm{k})}
$$

Where $k$ represents the lagged year, R\&D capital of a firm $i$ at time $t$. Research and development is represented by $\left(\mathrm{R}_{\mathrm{it}}\right)$ for a firm $i$ at time $t$, which depends on past and current $\mathrm{R} \& \mathrm{D}$ expenditures (RD). The weighting factor $\delta$ is the knowledge depreciation rate, which reflects the replacement of old 
knowledge by new knowledge (Tsai, 2005). The rate of obsolescence varies per year. Following (Kafouros, 2008a; Tsai, 2005) it was adopted $20 \%$ as the R\&D obsolescence rate.

\section{Intangible assets}

We measure the firm intangible assets following (Kayo et al., 2006). The authors measure the level of intangibility by using the firm Market Value of the shares (VM) over the total firm shareholders' equity. This ratio increases every year and can be an indicator of the level of intangibility of companies, indicating that the higher this index, the greater the intangibility participation in the firm market value (Kayo \& Famá, 2004; Kayo et al., 2006).

\section{Moderator variable firm size}

In order to examine whether the firm size moderates the innovation performance relationship we interacted the firm size with the firm knowledge (Research and Development) and Intangible (level of intangibility). The firm size variable is given by the total fixed assets used as a proxy (Griliches, 1979; Tsai, 2005). We take the logarithm of total fixed assets to construct this variable (Tsai, 2005; Viglioni et al., 2018).

\section{Control Variables}

Following the literature, we adopted several control variables. The firm age is measured as the natural logarithm of years since the firm was established in the market (Anderson \& Eshima, 2013; Berchici, 2013). We adopt this variable once a learning-by-doing process by the stock of intangible assets is cumulative in nature and will probably grow with the age of the firm (Berchici, 2013; Carboni $\&$ Medda, 2019). Thus, it is expected that the innovation performance for old firms may differ from young ones.

Finally, we adopted the technology intensity dummy equal 1, in case the firm is from the hightechnology sector and 0, otherwise. We considered such variable, once high-technology sectors particularly have a higher rate of growth (Dunning \& Lundan, 2008; Kafouros, 2008b). Low-tech firms tend to innovate less than large size high-tech firms (Aboal et al., 2015) and the influence of intangible assets on the value of companies can vary depending on the sector of activity (Kayo et al., 2006).

\section{Data and sample}

The sample consists of public shared firms listed in the Brazilian Securities and Exchange Commission (CVM) and B3 S.A. The DataStream provides the financial data of the Brazilian manufacturing firms. The data were collected on their annual reports. Our firm data consists of balanced panel data with 54 Brazilian manufacturing firms from the periods of 2009-2018, resulting in (540 
observations). The sample includes companies from various manufacturing sectors, as Table 1 summarize.

$\underline{\text { Table } 1 \text { - Firm sector and technology intensity }}$

\begin{tabular}{lccc}
\hline Industry sector & Number of firms & ISIC 4.0/4.1 & Technology intensity \\
\hline Food and beverage & 6 & $10 \& 11$ & Medium \\
Textile & 10 & 13 & Low \\
Paper and cellulose & 3 & 17 & Low \\
Oil and gas & 2 & 19 & Medium \\
Non-metallic minerals & 2 & 23 & Medium \\
Chemical and Pharmaceutical & 4 & 20 & High \\
Metallurgy & 10 & 24 & Medium \\
Industrial machinery & 3 & 28 & Medium \\
Communications equipment's & 2 & 27 & High \\
Electronics & 4 & 26 & High \\
Software & 2 & 28 & High \\
Automobile & 6 & 29 & High \\
\hline Total & 54 & & \\
\hline
\end{tabular}

Source: Authors (2020).

Companies from the service industry classified as banks, funds, and other industry sectors, such as agribusiness, civil engineering, energy, logistics, education, health, and transport were not included in the sample, once the objective of this paper is to analyze only manufacturing firms. Furthermore, there was an attempt to collect data before 2009, however, the adoption of Brazilian firms to International Financial Reporting Standards (IFRS) changed several of the accounting norms after 2008, restricting our data to 2009 to 2018 .

Table 2 presents means, standard deviations, as well as the correlation coefficients for all variables. Moreover, some variables possibly indicate high correlation issues and the tests indicated that this was not an issue to our model. Thus, the first procedure was to check any problem of multicollinearity and heteroskedasticity. Some variables present correlation above 0.60 (size and labor) and (size and R\&D). Nonetheless, the Breusch-Pagan, Cook-Weisberg and White's test for heteroskedasticity and Wooldridge (2002) test for autocorrelation did not indicate evidence of such problems. 
Table 2 - Observations, mean, standard deviation and correlations

\begin{tabular}{|c|c|c|c|c|c|c|c|c|c|c|}
\hline Variables & Obs. & Mean & S.D. & (1) & (2) & (3) & (4) & (5) & (6) & (7) \\
\hline (1) $\Delta$ Performance & 528 & 2.429 & 1.810 & 1.000 & & & & & & \\
\hline (2) $\Delta$ Capital & 461 & 2.447 & 1.428 & $0.374^{*}$ & 1.000 & & & & & \\
\hline (3) $\Delta$ Labor & 538 & 10.879 & 1.666 & $-0.285^{*}$ & $-0.191^{*}$ & 1.000 & & & & \\
\hline (4) $\Delta R \& D$ & 540 & 13.453 & 1.995 & $0.311^{*}$ & $0.406^{*}$ & $0.638^{*}$ & 1.000 & & & \\
\hline (5) $\Delta$ Intangibles & 460 & 0.239 & 0.994 & $0.123^{*}$ & $-0.237^{*}$ & $0.157^{*}$ & 0.043 & 1.000 & & \\
\hline (6) $\Delta$ Age & 540 & 4.078 & 0.573 & $-0.162^{*}$ & -0.046 & $-0.242^{*}$ & $-0.183^{*}$ & -0.091 & 1.000 & \\
\hline (7) $\Delta$ Firm size & 540 & 14.803 & 1.952 & $-0.012^{*}$ & $0.219^{*}$ & $0.849^{*}$ & $0.786^{*}$ & 0.094 & $-0.316^{*}$ & 1.000 \\
\hline
\end{tabular}

Note: $(1) *$ shows significance at the .01 level of significance.

Source: Authors (2020).

The second procedure was to identify the best panel using the Hausman test as a standard statistical procedure to verify endogeneity problems (Cameron \& Trivedi, 2010). The Hausman test compares the FE (fixed effect) and RE (random effect) estimators with the time-varying estimated coefficients or a subset of key regressors (Cameron \& Trivedi, 2010). The test indicated at 1 percent of significance, that the most appropriate choice for our panel was the random effects panel.

\section{Results and discussion}

Table 3 reports the regression findings considering the relationship between $R \& D$ and firm size. The $\mathrm{R}^{2}$ is in accordance with the literature (Anderson \& Eshima, 2013; Kafouros et al., 2008; Kafouros et al., 2009), but slightly higher compared to these studies. Model 1 includes only independent and control variables to check its respective effects. Model 2 includes the variables from the later model plus the industry and time dummies. Finally, Model 3 checks the regression results with all variables with the interaction effect between firm knowledge and size.

Table 3 - Regression results - Research and Development and firm size

\begin{tabular}{lccc}
\hline & Model 1 & Model 2 & Model 3 \\
\hline Capital & $-0.111^{* * *}(0.057)$ & $-0.088(0.056)$ & $-0.094^{*}(0.056)$ \\
Labor & $-0.393^{* * * *}(0.082)$ & $-0.337^{* * *}(0.080)$ & $-0.328^{* * * *}(0.080)$ \\
R\&D & $0.268^{* * *}(0.064)$ & $0.218^{* * * *}(0.064)$ & $1.016^{* * * *}(0.229)$ \\
Size & $0.029(0.083)$ & $0.058(0.083)$ & $0.829^{* * * *}(0.232)$ \\
R\&D $\times$ Size & & & $-0.054^{* * * *}(0.015)$ \\
Firm age & $0.303^{* * *}(0.147)$ & $0.388^{* * * *}(0.147)$ & $0.290^{* *}(0.148)$ \\
High /Low-tech dummy & $1.131^{* * *}(0.405)$ & $1.887^{* * * *}(.660)$ & $1.802^{* * * *}(0.627)$ \\
const & $1.423(0.971)$ & $0.497(1.089)$ & $-10.227^{* * *}(3.196)$ \\
Industry dummy & No & Yes & Yes \\
Time dummy & No & Yes & Yes \\
Wald Schi2 & $53.92^{* * * *}$ & $96.75^{* * *}$ & $114.84^{* * *}$ \\
$\mathrm{R}^{2}$ & 0.356 & 0.358 & 0.402 \\
$\mathrm{R}^{2}$ adjusted & 0.404 & 0.373 & 0.416 \\
\hline
\end{tabular}

Note: (1) The dependent variable is represented by the firm value-added; (2) The standard errors are included in the parentheses; (3)* if $\mathrm{p}<0.10, * *$ if $\mathrm{p}<0.05 ; * * *$ if $\mathrm{p}<0.01$.

Source: Authors (2020). 
It is possible to observe in Model 2 that the R\&D coefficient shows high and positive significance $(\beta=0.218, p<0.000)$. The result supports the hypothesis $(1)$ with the idea that $R \& D$ expenditures improve the firm innovation performance, also this result was not a surprise. This indicates that 1 percent of investment in $R \& D$ generates 0.218 percent to the firm value-added. Our result also shows that firms generate value-added resulting in superior sales (Crespi \& Zuniga, 2012) when invested in $R \& D$ activities. Nevertheless, the returns on $R \& D$ is kind lower. Additionally, the result goes in a different direction of Viglioni and Calegario (2020). Using industry-level data, the authors found that R\&D does not show significance in short-term. Moreover, it is possible to observe that the dummy for technology intensity shows a high and positive significance $(\beta=1.887, \mathrm{p}<0.000)$. We argue in the same direction as Berchicci (2013) when the authors suggested that Italian manufacturing firms with greater $R \& D$ capacity perform systematically better than those with a lower level of R\&D. In addition, besides these results, we found that the labor variable shows significance in all models, but with a negative coefficient. This finding could be related to a possible labor constraint on manufacturing industries.

Considering the Model 3, interaction between size and $R \& D(\beta=-0.054, p<0.000)$ shows a negative effect on the firm performance, whilst $R \& D(\beta=1.016, p<0.000)$ and size $(\beta=0.829, p<$ $0.000)$ improves the firm performance when these variables work isolated. Considering this, we reject the hypothesis (3a) and the idea that firm innovation performance is positively moderated by the size of the firm and $R \& D$ expenditures. This result is very important considering the firm size and $R \& D$ capacity because it is possible to argue that size does not have a relation with the firm $R \& D$ investments as the literature suggested.

In addition, firm age shows positive significance in all models, indicating that old firms perform better than younger ones. This result is expected and possibly related to the firm size, Model 3, once larger and older firms have sources of capital acquired across the years. Nonetheless, our results go in a different direction from the literature, once Carboni \& Medda (2019) suggested that younger firms might have more business dynamism, whilst Shefer \& Frenkel (2005) argued there is a large number of young startups working with R\&D. Considering this result, both authors analyzed different contexts, once they investigated advanced economies, where the business dynamics and investment of young firms are very different from emerging economies.

Moreover, the dummy for the high technology industry shows a positive coefficient $(\beta=1.802$, $\mathrm{p}<0.000$ ), which is not a surprise, once high technology firms, in general, show better performance results when compared to medium-low tech firms. This result goes in the same way as Aboal et al. (2015), Berchicci (2013), and Kafouros et al. (2009), when the authors suggested that low-tech firms tend to innovate less than the high-tech firms, such as electronics, pharmaceuticals, telecommunications, computers, software and aircraft, and generate higher-value products. Nonetheless, as observed earlier, in Model 3, high-tech firms do not necessarily need to have higher performance when R\&D is weighted by the firm size. 
Table 4 shows the regression results for the relationship between the degree of intangibles assets and firm size. The Model 2 indicates that firm intangibles assets $(\beta=0.315, p<0.000)$ improve the firm performance. This result allows us to accept hypothesis (2) and the idea that a firm investment in intangibles assets contribute positively to innovation performance. Nevertheless, comparing with the $R \& D$ regression, Table $3(\beta=0.218, p<0.000)$, Model 2 , it is possible to observe that firm investments in $R \& D$ is lower if compared to intangible assets coefficient, Table 4 ( $\beta=0.315, p<0.000)$, Model 2 . This result is important for several reasons. $R \& D$ activities, in general, are very expensive and need a long time to improve the firm performance. Second, the literature predicts that $R \& D$ investments, in general, are carried by large or high-technology intensive firms, due to their financial and capital capacity to sustain this kind of investments. Third, not all firms in emerging economies are prepared to invest in $\mathrm{R} \& \mathrm{D}$ and create radical products and process applications.

Table 4 - Regression results - level of intangible assets and firm size

\begin{tabular}{lccc}
\hline & Model 1 & Model 2 & Model 3 \\
\hline Capital & $0.014(0.053)$ & $0.031(0.052)$ & $0.032(0.052)$ \\
Labor & $-0.146^{*}(0.081)$ & $-0.104(0.079)$ & $-0.075(0.080)$ \\
Intangibles & $0.304^{* * * *}(0.057)$ & $0.315^{* * *}(0.058)$ & $-0.601(0.428)$ \\
Size & $0.038(0.077)$ & $0.013(0.076)$ & $-0.027(0.079)$ \\
Intangibles $\times$ Size & & & $0.061^{* *}(0.028)$ \\
Firm age & $0.507^{* * * *}(0.153)$ & $0.534^{* * *}(0.151)$ & $0.518^{* * *}(0.151)$ \\
High /Low-tech dummy & $0.995^{*}(0.532)$ & $2.083^{* * *}(0.871)$ & $2.003^{* *}(0.832)$ \\
const & $1.206(1.004)$ & $0.632(1.208)$ & $1.031(1.201)$ \\
Industry dummy & No & Yes & Yes \\
Time dummy & No & Yes & Yes \\
Wald Schi2 & $56.52^{* * *}$ & $102.21^{* * *}$ & $107.92^{* * *}$ \\
$\mathrm{R}^{2}$ & 0.045 & 0.261 & 0.267 \\
$\mathrm{R}^{2}$ adjusted & 0.065 & 0.240 & 0.246 \\
\hline
\end{tabular}

Note: (1) The dependent variable is represented by the firm value-added; (2) The standard errors are included in the parentheses; (3) * if $\mathrm{p}<0.10, * *$ if $\mathrm{p}<0.05 ; * * *$ if $\mathrm{p}<0.01$.

Source: The authors (2020).

Considering this, we suggest that, intangible assets, such as brand name, consumers' preference and their perception of the products or services as well as firm marketing and organizational capabilities, that improve the firm market value, are also essential for the economic growth of Brazilian firms (Viglioni et al., 2018). In the last decade, several Brazilian firms have developed strong brand names in their home country and in the international market as well. Nonetheless, these activities do not necessarily need to be precisely related to $R \& D$ expenditures in their most pure form (new product and process). In the same line, Andonova and Ruíz-Pava (2016) found evidence that confirms the resilience of intangible assets as drivers of competitive advantage in an emerging environment. 
In Model 3, it is possible to identify that several variables do not show statistical significance, including capital $(\beta=0.032, \mathrm{p}>0.10)$, labor $(\beta=-0.075, \mathrm{p}>0.10)$, intangible assets $(\beta=-0.601, \mathrm{p}>$ $0.10)$ and firm size $(\beta=-0.027, p>0.10)$. Nonetheless, we found an interesting result, when the firm intangible assets and size interact $(\beta=0.061, \mathrm{p}<0.05)$, supporting the hypothesis $(3 \mathrm{~b})$ and the idea that firm innovation performance is positively moderated by these relationships. Our result goes in the same direction as (Aboal et al., 2015; Arrighetti et al., 2014; Kafouros \& Aliyev, 2016), but different from Carvalho et al. (2010) when the authors suggested that intangible assets affect negatively the Brazilian firm performance.

This finding has important implications for our research. Intangible assets only show a positive impact on the firm performance when it interacts with the firm size. This could be explained by the RBV theory, once large firms have more capital to acquire others, considering their intangibles, such as brands, patents, customer preferences, and other related intangible assets as pointed by (Kayo et al., 2006; Viglioni et al., 2018). This result provides a better vision about intangible assets, indicating the role of intangible, such as the brand, name, patents, and other knowledge relevant to the firm develop of new products and value generation. This result goes in a similar direction (Kafouros \& Aliyev, 2016). This is important, once there is a large number of Brazilian firms working in foreign countries (Viglioni \& Calegario, 2020). Thus, we suggest that large size firms are more capable to handle different environments.

In addition, the firm age is, again, positive to the firm's performance $(\beta=0.518, p<0.000)$. This occurs once, in general, old firms are more capable to expand their activities, whilst younger ones have a resource disadvantaged (Anderson \& Eshima, 2013). As mentioned by Berchici (2013) and Carboni and Medda (2019), firm age is related to the learning-by-doing process, which means that the stock of intangible assets is cumulative in nature and will probably grow with the age of the firm. Finally, the coefficient $(\beta=2.003, \mathrm{p}<0.050)$ for high-technology firms remains positive, which means hightech firms have higher performance due to their size and intangible assets.

\section{Limitations and future contributions}

The intention of this paper was not to generalize or stress any result but to understand the implication of the firm innovation performance and the relationship between $R \& D$, intangible assets, and firm size. The research limitation consists in the R\&D variable, once we adopt a proxy to measure the firm research and development intensity. Nonetheless, it was necessary, once firms in Brazil rarely disclose information in the balance sheet related to $R \& D$ expenditures. Considering these observations, we suggest for future researches that this type of analysis may be performed at the firm-level with new variables, measures, and methods of analysis. Related to intangible assets, we encourage researchers to moderate other important firm advantages, apart from the firm size. Finally, alternative measures of 
intangible assets could be implemented, once there are several definitions and approaches across the literature.

\section{Conclusions}

As an objective of the present study, we aimed to understand how firm size moderates the firm knowledge and improves the innovation performance in Brazilian manufacturing firms. Following the RBV theory, we investigated how the firm internal R\&D and the degree of intangible assets are moderated by firm size. Our results show that Brazilian firm investments are crucial for the development of innovation, as the literature confirms. Investing in $R \& D$ is relevant to improve the firm performance. Nonetheless, we had not concluded that the firm performance is moderated by R\&D and firm size, which contradicts the notion that large size firms are more R\&D intensive.

The main findings for $R \& D$ indicate that a firm performance is affected negatively when $R \& D$ and firm size interact. This result is important, once it may be a sign that medium-and-small sized firms are engaging in these activities. In the case of intangible assets, they did not show improvements to the firm performance, except when the firm size moderates the degree of intangible assets. Finally, the results indicate that old firms are prone to engage in innovation, probably because their own capacity to finance their activities and intangible assets grow across time. In the same way, firm technology intensity shows an important factor in the firm investment in R\&D and intangible assets.

\section{Acknowledgments}

The authors thank the Editor and the anonymous reviewers for their helpful comments and critical insights. We also thank The European International Business Academy (EIBA) $45^{\text {th }}$ EIBA 2019 Leeds Conference for accepting this paper and for the insightful comments of the anonymous reviewers. At last but not least, we thank the Coordination for the Improvement of Higher Education Personnel (Coordenação de Aperfeiçoamento de Pessoal de Nível Superior-CAPES).

\section{References}

Aboal, D., Garda, G., Lanzilotta, B., \& Perera, M. (2015). Innovation, firm size, technology intensity, and employment generation: Evidence from the Uruguayan manufacturing sector, Emerging Markets Finance and Trade, 51(1), 3-26.

Alcorta, L., \& Peres, W. (1998). Innovation systems and technological specialization in Latin America and the Caribbean. Research Policy, 26(7-8), 857-81.

Anderson, B. S., \& Eshima, Y. (2013). The influence of firm age and intangible resources on the relationship between entrepreneurial orientation and firm growth among Japanese SMEs. Journal of Business Venturing, 28(3), 413-429.

Andonova, V., \& Ruíz-Pava, G. (2016). The role of industry factors and intangible assets in company performance in Colombia. Journal of Business Research, 69(10), 4377-4384. 
Arrighetti, A., Landini, F., \& Lasagni, A. (2014). Intangible assets and firm heterogeneity: Evidence from Italy. Research Policy, 43, 202-213.

Arza, V., \& Lopez, A. (2010). Innovation and productivity in the Argentine manufacturing sector. IDB working paper, no., 187, Washington, DC.

Barney, J. B. (1991). Firm resources and sustained competitive advantage. Journal of Management, 17(1), 99-120.

Benavente, J. M. (2006). The role of research and innovation in promoting productivity in Chile. Economics of Innovation and New Technology, 15(4-5), 301-315.

Berchicci, L. (2013). Towards an open R\&D system: Internal R\&D investment, external knowledge acquisition and innovative performance. Research Policy, 42(1), 117-127.

Bontempi, M. E., \& Mairesse, J. (2015). Intangible capital and productivity at the firm level: a panel data assessment. Economics of Innovation and New Technology, 24(1-2), 22-51.

Bravo-Ortega, C., Benavente, J. M., \& González, A. (2014). Innovation, Exports, and Productivity: Learning and Self-Selection in Chile. Emerging Markets Finance and Trade, 50(1), 68-95.

Bueno, E., Aragón, J. A., Salmador, M. P., \& García, V. J. (2010). Tangible slack versus intangible resources: the influence of technology slack and tacit knowledge on the capability of organizational learning to generate innovation and performance. International Jounal of Technology Management, 49(4), 314-337.

Cameron, C. A., \& Trivedi, P. K. (2010). Microeconometrics Using Stata. Revised Edition, Stata Press.

Carboni, O. A., \& Medda G. (2019). Does R\&D spending boost tangible investment? An analysis on European firms, Applied Economics, 1-17.

Carvalho, F. M., Kayo, E. K., \& Martin, D. M. L. (2010). Tangibilidade e intangibilidade na determinação do desempenho persistente de firmas Brasileiras. Revista de Administração Contemporânea, 14(5), 871-889.

Chudnovsky, D., López, A., \& Pupato, G. (2006). Innovation and productivity in developing countries: A study of Argentine manufacturing firms' behavior (1992-2001). Research Policy, 35(2), 266-288.

Crespi, G. A., Arias-Ortiz, E., Tacsir, E., Vargas, F., \& Zuniga, P. (2014). Innovation for economic performance: the case of Latin American firms. Eurasian Business Review, 4(1), 31-50.

Crespi, G., \& Zuniga, P. (2012). Innovation and Productivity: Evidence from Six Latin American Countries. World Development, 40(2), 273-290.

Denicolai, S., Ramusino, E. C., \& Sotti, F. (2015) The impact of intangibles on firm growth. Technology Analysis \& Strategic Management, 27(2), 219-236.

Dierickx, I., \& Cool, K. (1989). Asset Stock Accumulation and Sustainability of Competitive Advantage. Management Science, 35, 1504-1511.

Dunning, J., \& Lundan, S. (2008). Multinational enterprises and the global economy. (2nd ed.). Cheltenham: E. Elgar. 
Fagerberg, J., Srholec, M., \& Verspagen, B. (2010). Innovation and economic development. In: Arrow, J. K., \& Intriligator, M. D. Handbook of the Economics of Innovation, Elsevier, (2), 833872.

Frank, A. G., Cortimiglia, M. N., Ribeiro, J. L D., \& Oliveira., L. S. (2016). The effect of innovation activities on innovation outputs in the Brazilian industry: Market-orientation vs. technologyacquisition strategies. Research Policy, 45, 577-592.

Gantumur, T., \& Stephan, A. (2012). Mergers \& acquisitions and innovation performance in the telecommunications equipment industry. Industrial and Corporate Change, 21(2), 277-314.

Griliches, Z. (1979). Issues in assessing the contribution of research and development to productivity growth. Bell Journal of Economics, 10(1), 92-116.

Hall, B. H., \& Mairesse, J. (1995). Exploring the relationship between R\&D and productivity in French manufacturing firms. Journal of Econometrics, 65, 263-293.

Hall, B. H., Mairesse, J., \& Mohnen, P. (2010). Measuring the returns to R\&D. In Arrow, J. K., \& Intriligator, M. D. Handbook of the economics of innovation, Elsevier, (2), 1033-1082.

Hall, R. (1992). The strategic analysis of intangible resources. Strategic Management Journal, 13, 135-44.

James, A. D. (2002). The strategic management of mergers and acquisitions in the pharmaceutical industry: Developing a resource-based perspective. Technology Analysis \& Strategic Management, 14(3), 299-313.

Kafouros, M. I. (2008a). Industrial Innovation and Firm Performance: The Impact of Scientific Knowledge on Multinational Corporations. Edward Elgar.

Kafouros, M. I. (2008b). Economic returns to industrial research. Journal of Business Research, 61(8), 868-876.

Kafouros, M., \& Aliyev, M. (2016). Institutions and Foreign Subsidiary Growth in Transition Economies: The Role of Intangible Assets and Capabilities. Journal of Management Studies, 53(4), 580-607.

Kafouros, M., Wang, C., \& Lodorfos, G. (2009). The impact of R\&D strategy and firm size on the returns to innovation. International Journal of Entrepreneurship and Small Business, 8(4), 550-566.

Kayo, E. K., \& Famá, R. (2004). A estrutura de capital e o risco das empresas tangível-intensivas e intangível-intensivas. Revista de Administração, 39(2), 164-176.

Kayo, E. K., Kimura, H., Martin, D. M. L., \& Nakamura, W, T. (2006). Ativos intangíveis, ciclo de vida e criação de valor. Revista de Administração Contemporânea, 10(3), 73-90.

Kramer, J-P., Marinelli, E., Iammarino, S., \& Diez, J. R. (2011). Intangible assets as drivers of innovation: Empirical evidence on multinational enterprises in German and UK regional systems of innovation. Technovation, 31(9), 447-458.

Lev, B. (2001). Intangibles: Management, measurement, and reporting. Brookings Institution Press, Washington, DC. 
Luca, M. M. M., Maia, A. B. G. R., Cardoso, V. I. C., Vasconcelos, A. C., \& Cunha, J. V. A. (2014). Intangible assets and superior and sustained performance of innovative Brazilian firms. Brazilian Administration Review, 11(4), 407-440.

Mansfield, E., Rapoport, J., Schnee, J., Wagner, S., \& Hamburger, M. (1971). Research and innovation in the modern corporation. New York: W. W. Norton.

Monteiro, A, P., Soares, A. M., \& Rua, O. L. (2013). Export performance: Influence of intangible resources, dynamic capabilities and entrepreneurial. Iberoamerican Journal of Strategic Management, 12(3), 12-36.

Navarro, J. C., Benavente, J. M., \& Crespi. G. (2016). The New imperative of innovation: Policy perspectives for Latin America and the Caribbean. Inter-American Development Bank, Washington DC.

OECD. (2015). Frascati Manual 2015: Guidelines for collecting and reporting data on research and experimental development, The measurement of scientific, technological and innovation Activities. OECD Publishing, Paris. 6th Edition.

Penrose, E. T. (1959). The theory of the growth of the firm. New York: John Wiley.

Peteraf, M. A., \& Barney, J. B. (2003). Unraveling the resource-based tangle. Managerial and Decision Economics, 24, 309-323.

Restrepo-Morales, J. A., Loaiza, O. L., \& Vanegas, J. G. (2019). Determinants of innovation: A multivariate analysis in Colombian micro, small and medium-sized enterprises. Journal of Economics, Finance and Administrative Science, 24(47), 97-112.

Schumpeter, J. (1942). Capitalism, socialism, and democracy. New York: Harper \& Bros

Shefer, D., \& Frenkel, A. (2005). R\&D, firm size and innovation: An empirical analysis, Technovation, 25(1), 25-32.

Solow, R, M. (1956). A Contribution to the theory of economic growth. The Quarterly Journal of Economics, 70(1), 65-94.

Suzuki, K. (1985). Knowledge capital and the private rate of return to R\&D in Japanese manufacturing industries. International Journal of Industrial Organization, 3, 293-305.

Tsai, K-H. (2005). R\&D productivity and firm size: a nonlinear examination. Technovation, 25, 795803.

Viglioni, M. T. D., \& Calegario, C. L. L. (2020). Home country innovation performance: Moderating the local knowledge and inward foreign direct investment. Global Business Review.

Viglioni, M. T. D., Carvalho, F. M., Benedicto, G. C., \& Prado, J. W. (2018). Indicadores EconômicoFinanceiros Determinantes de Fusões e Aquisições: um Estudo na Indústria de Tecnologia no Brasil. Contabilidade, Gestão e Governança, 21(3), 420-438.

Wakelin, K. (2001). Productivity growth and R\&D expenditure in UK manufacturing firms. Research policy, 30, 1079-1090.

Wooldridge, J. M. (2002). Econometric Analysis of Cross Section and Panel Data. The MIT Press. Cambridge, Massachusetts. London, England. 